\title{
Straw Mulch and Restricted Irrigation Effect on Productivity, Profitability and Water Use in Wheat (Triticum aestivum L.) under Various Crop Establishment Techniques in Eastern Sub-Himalayan Plains of India
}

\author{
Prantick Singha, Triptesh Mondal, Koushik Patra and Biplab Mitra* \\ Department of Agronomy, Uttar Banga Krishi Viswavidyalaya, Pundibari, Coochbehar, \\ West Bengal-736 165, India \\ *Corresponding author
}

\section{Keywords}

Bed planting,

Economics, Mulching,

Restricted irrigation,

Wheat, Zero tillage

Article Info

Accepted:

15 January 2018

Available Online:

10 February 2018

\section{A B S T R A C T}

An experiment was carried out in eastern sub-Himalayan plains of India to assess the performances of wheat (Triticum aestivum L.) under various crop establishment techniques and to find out the influence of mulching and irrigation on productivity, moisture use and profitability of wheat cultivation. Results indicated the superiority of bed planting (BP) in terms of biomass production and grain yield over zero tillage (ZT) and conventional tillage (CT). Significantly higher biomass was recorded under bed planting (BP) over that under conventional tillage (CT) and zero tillage (ZT). Grain yield was increased by 13 and $16.9 \%$ under BP over that under CT during 2015-16 and 2016-17, respectively. Grain yield increased significantly under mulch treated plots over that under non-mulched plots, irrespective of irrigation levels. Least water use with higher water use efficiency and water productivity were measured under BP. Under all three crop establishment techniques, contribution of top 0-15 cm layer was maximum towards total moisture use by the crop where straw mulch was used. While in non-mulch treatment, there was no definite trend in moisture extraction pattern as contributed by various layers. However, increase in number of irrigation further increased the moisture availability in top $0-15 \mathrm{~cm}$ soil layer. The maximum benefit-cost (B: C) ratio (2.68) was recorded under BP with mulching and three irrigations. It was revealed that BP along with paddy straw mulching @ $4 \mathrm{t} / \mathrm{ha}$ and three irrigations is a good option for the wheat farmers of the Eastern sub-Himalayan plains in terms of productivity, water use and profitability.

\section{Introduction}

The rice (Oryza sativa L.)-wheat (Triticum aestivum L.) cropping system of IndoGangetic Plains (IGP) is important for food security vis-a-vis livelihoods for millions of rural and urban people in the region. In recent past, a lot of evidences suggest that sustainability of this important system is at risk as the productivity of the system is static for past several years and total factor productivity is declining due to increasing water scarcity, changing climatic scenario as well as increased labour shortage with escalating fuel prices. The indiscriminate use of natural resources, especially water, has led to pollution and depletion of ground water resources (Nayar and Gill, 1994). The 
situation is serious; if it is not improved, India may face water wars in the near future. Depleting soil organic C status, decreasing soil fertility and reduced factor productivity are other issues of concern (Yadav, 1998). This evidence indicates that the rice-wheat (RW) system, especially intensive tillage and injudicious use of water under conventional tillage (CT) system has weakened the natural resource base. If exploitation of natural resources at the current level continues, productivity and sustainability are bound to suffer (Mann et al., 2008). Therefore, to achieve sustainable or higher productivity, efforts must be focused on reversing the trend in natural resource degradation.

In the high yielding wheat production systems in North Western part of country (Wheat bowl of India), intensive tillage operations and blanket fertilizer recommendations have led to high production costs, decreased nutrient use efficiency, lower profits and significant environmental externalities. This is applicable for the wheat growing belt of Eastern subHimalayan plains also where wheat is being cultivated with intensive tillage operations and injudicious rate of fertilizer application. As a result, zero tillage (ZT) technology has been increasingly adopted in this region to reduce costs and increased input use efficiency in wheat cultivation (Mitra and Das, 2015). It saves time requires for conventional field preparation and is eco-friendly also owing to very low fuel requirement compared to traditional system of wheat cultivation. Energy requirement for wheat cultivation is minimum for zero tillage and maximum for conventional tillage (Chauhan et al., 2003, Sharma et al., 2007). Bed planting (BP) method is an approach for optimum fertilizer and water use efficiency as well as higher yield compared to conventional flat method as the bed planting method increased the water use efficiency and fertilizer use efficiency to a considerable extent (Naresh et al., 2011; Bhuyan et al.,
2012). Bed planting in rice-wheat cropping systems is new in this part of the country but it may be perceived as a technique for improving resource use efficiency. However, there was no systematic work carried out previously in this zone with respect to the amount of water saved under bed planting or actual water use under bed planting.

Growing wheat under restricted irrigation with mulching may also serve as viable alternatives in present day context. Mulching reduces the deterioration of soil by the way of preventing the runoff and soil loss, minimizes the weed infestation and reduces water evaporation. Thus, it facilitates more retention of soil moisture and helps in control of temperature fluctuations, improves physical, chemical and biological properties of soil, as it adds nutrients to the soil and ultimately enhances the growth and yield of crops (Dilip Kumar et al., 1990).In this part of the country attempts have been made for growing wheat under rainfed condition and it was found that some varieties like HD 3016 can successfully be grown under rainfed condition utilizing the residual moisture (Das and Mitra, 2011). As the cessation of monsoon rain is late in this part, soil holds a fair amount of moisture during November-December. In most of the cases, farmers have to wait for 3-4 weeks after harvesting kharif (commencing from JuneJuly) paddy to introduce wheat in the field due to high soil moisture. Mulching may be a good option here to utilize the moisture to its fullest. Moreover, the added benefits will be the reduction in number of irrigation to the crop. With this background, the present investigation was formulated to find out the influence of mulching and lesser number of irrigation on productivity and profitability of wheat under various crop establishment techniques and to determine the actual water use by the crop under mulch and non-mulch systems for all crop establishment techniques, viz., CT, ZT and BP. 


\section{Materials and Methods}

The experiment was conducted at the instructional farm of Uttar Banga Krishi Viswavidyalaya, Pundibari, Coochbehar located at $26^{\circ} 24^{\prime} 02.2^{\prime \prime} \mathrm{N}$ latitude, $89^{\circ} 23^{\prime} 21.7^{\prime \prime} \mathrm{E}$ longitude and at an elevation of 43 meters above mean sea level. It was carried out for two consecutive years, i.e., rabi, 201516 and 2016-17. The experimental soil was sandy loam in texture with $\mathrm{pH}-5.80$, Organic $\mathrm{C}(\%)-0.88$, mineralizable $\mathrm{N}-250.8 \mathrm{~kg} / \mathrm{ha}$, available $\mathrm{P}-28.2 \mathrm{~kg} / \mathrm{ha}$ and available K-142.9 $\mathrm{kg} / \mathrm{ha}$. The experiment was laid out in a split plot design having 18 treatment combinations. Three different crop establishment techniques, viz., Zero tillage(ZT), bed planting(BP) and conventional tillage(CT) were randomly allotted in each main plot, while within each main plot, six treatments comprising mulching x irrigation, viz., straw mulch @ 4 t/ha, no Irrigation; straw mulch @ 4 t/ha, one Irrigation at CRI; straw mulch @ $4 \mathrm{t} / \mathrm{ha}$, three Irrigations at CRI, booting and milking Stage; no mulch, no irrigation; one irrigation at CRI without mulch; three irrigations at CRI, booting and milking without mulch were randomly allocated as sub-plots. The treatments were replicated thrice. The sizes of each experimental plot were $6 \mathrm{~m} \times 5.4 \mathrm{~m}$.

For CT, the land was prepared by ploughing twice with a cultivator and rotovator and then the soil was brought into good tilth with a power tiller. Land levelling was done with ladder. However, no land preparation was done for ZT and BP. Zero tillage was done with zero till drill while bed planting was done with 2-wheel drive bed planter through which loose $6-10 \mathrm{~cm}$ high temporary beds were formed with a single pass within previous rice crop stubbles. The width of the beds was 50 $\mathrm{cm}$ in which two rows of wheat at $20 \mathrm{~cm}$ rows apart were sown. Seeds were also sown in lines $20 \mathrm{~cm}$ apart in ZT and CT with a seed rate of $100 \mathrm{~kg} \mathrm{ha}^{-1}$. The variety used in the experiment was $\mathrm{K} 0307$, recommended for NEPZ under timely sown irrigated condition with an average yield of 4.5 t/ha. The recommended doses of fertilizers (150-60-40 $\mathrm{kg} / \mathrm{ha}$ of $\mathrm{N}-\mathrm{P}_{2} \mathrm{O}_{5}-\mathrm{K}_{2} \mathrm{O}$ ) were applied in all CT, $\mathrm{ZT}$ and BP plots. The half of $\mathrm{N}$ along with full $\mathrm{P}$ and $\mathrm{K}$ were applied as basal, while the rest of the $\mathrm{N}$ was applied at CRI stage. Glyphosate 41\% S.L. @ 3.75 litre/ha was applied 7 days prior to sowing for killing the existing weed flora and broad-leaved weeds were controlled with 2,4-D Na salt $80 \%$ W.P. @ $1 \mathrm{~kg} / \mathrm{ha}$ at 4-5 weeks after sowing. In conventional tillage plots, thinning and weeding were done simultaneously with the help of manual labour at 3-4 weeks after sowing. Boron (B) was applied twice, i.e., @ 0.20\% with Solubor (B $20 \%$ ), once at 35-40 days after sowing (DAS) and the next at 55-60 DAS under all crop establishment techniques. Zinc (Zn) was applied@ 0.10\% with B in the second spray with Chelated $\mathrm{Zn}$. In both the years, irrigations were given based on treatment. Check basin method of irrigation was followed keeping the depth of irrigation at $5 \mathrm{~cm}$ measured through volume basis. The volume of water in individual field was measured with the flow meter installed at the pump for irrigation and recording time for irrigation. Harvesting of the crop was done manually and yield was estimated on net plot basis excluding the border rows. After harvesting, the produce was threshed and grains were dried to record yield.

Soil moisture percentage was determined using soil moisture probe. To study the moisture extraction patterns, soil samples were taken just before irrigation and 24 hours after irrigation from $0-15,15-30$ and $30-45 \mathrm{~cm}$ depth with the help of the screw soil auger. Soil samples were also taken from the nonirrigated treatments at that time. Immediately the samples were transferred to aluminium soil moisture boxes and covered with moist gunny bag to avoid moisture losses from soil 
samples. The moisture boxes containing soil samples were shifted immediately to laboratory for weighing and drying. The soil samples were dried at $105^{\circ} \mathrm{C} 72$ hours.

Soil moisture studies were started right from sowing and continued up to final harvest of the crop. Moisture percentage from different layers was determined on oven dry weight basis.

\begin{tabular}{|c|c|c|}
\hline Moisture & & percentage \\
\hline wet sample & weight & - dry sample \\
\hline
\end{tabular}

The profile contribution of soil moisture was determined with the help of change of moisture status between sowing and harvesting of the crop. The total use of water was calculated with the following formula:

$$
\sum_{i=1}^{n} \frac{M_{1 i}-M_{2 i}}{100} x B D_{i} \times D_{i}+E R+G C
$$

Where,

$\mathrm{n}=$ Number of soil layers sampled in the rootzone depth ' $\mathrm{D}$ '

$\mathrm{M}_{1 \mathrm{i}}=$ Soil moisture percentage at the time of first sampling

$\mathrm{M}_{2 \mathrm{i}}=$ Soil moisture percentage at the time of second sampling

$\mathrm{BD}_{\mathrm{i}}=$ Bulk density of ith soil layer $(\mathrm{g} / \mathrm{cc})$

$\mathrm{D}_{\mathrm{i}}=$ Depth of ith soil layer $(\mathrm{cm})$

$\mathrm{ER}=$ Effective rainfall $(\mathrm{cm})$

$\mathrm{GC}=$ Ground water contribution

There was no ground water contribution as the depth of ground water from soil surface was below 3 feet.

Water use efficiency (WUE) is defined as yield of marketable crop produced per unit of water used in evapo-transpiration (ET). WUE was determined by taking seasonal consumptive use values of different treatments and yields of that treatment using the following formula:

WUE $(\mathrm{kg} / \mathrm{ha} / \mathrm{mm})=$ Yield $(\mathrm{kg} / \mathrm{ha}) / \mathrm{ET}$ or CU value $(\mathrm{mm})$

Water productivity was computed based on yield divided by total water required for the growing period in cubic meters. It was indicative of the yield per unit usage of water.

Total cost of production per ha for each treatment was calculated on the basis of existing market rate of inputs by taking into account the cost of seeds, fertilizers, pesticides, hiring charges for machineries and labour use. The cost incurred for all activities starting from land preparation to harvesting and threshing was taken into consideration. Gross return was calculated on the basis of prevailing market price of the produce fixed by the Government of West Bengal, India and accordingly net profit was calculated based on the difference between gross return and the total cost of cultivation. All the figures were expressed in Indian Rupee ( $\square$ ). Benefit: Cost (B: C) ratio was calculated based on the ratio of gross income to total cost of cultivation. On the basis of $\mathrm{B}$ : $\mathrm{C}$ ratio, the most beneficial treatment for the crop sequence was determined.

Analysis of variance method was used for statistical analyses and for drawing conclusions. The significance of various sources of variation was tested by error mean square by Fisher-Snedecorst "F" Test at probability levels 0.05 (Cochran and Cox, 
1955; Panse and Sukhatme, 1967). For comparison of ' $F$ ' tables and for computation of critical differences, Fisher and Yates table was consulted. The interaction effect between main plot (crop establishment techniques) and sub plot (mulch $\times$ irrigation) was nonsignificant for all the characters. That is why emphasis in this paper was given on main effects of crop establishment techniques (main plot) and mulch $\times$ irrigation (sub-plot) together. Quantification of individual effect of either mulch or irrigation was not done in the present study.

\section{Results and Discussion}

\section{Yield attributes}

Number of spike $\mathrm{m}^{-2}$ as well as number of filled grains spike ${ }^{-1}$ were found to differ significantly under various crop establishment techniques during both the year of experimentation. Maximum number of spike/m $\mathrm{m}^{2}$ (319 and 324 during 2015-16 and 2016-17, respectively) with maximum number of filled grains/spike (40 and 41 during 201516 and 2016-17, respectively) was recorded with BP (Table 1). The number of spike $/ \mathrm{m}^{2}$ under BP was 14.4 and $14.9 \%$ higher than CT during year I and year II, respectively. No significant difference in spike length and test weight was observed under various crop establishment techniques, i.e., CT, ZT and BP during both the years of experimentation. However, in all the cases BP recorded higher spike length (17.6 and $17.9 \mathrm{~cm}$ during year I and year II, respectively) accommodating more number of grains/spike. In both the years of experimentation, 1000-grain weight, being a genetic character, did not vary significantly under various crop establishment techniques.

The treatments comprising three irrigation along with mulching @ 4 t/ha recorded significantly higher number of spike/m ${ }^{2}$ (409 and 400 during 2015-16 and 2016-17,
respectively).It was followed by the treatments receiving one irrigation with mulching (346 and 333 during 2015-16 and 2016-17, respectively). The plots where no mulch and irrigation was applied, the number of spike $/ \mathrm{m}^{2}$ were recorded to be the lowest (192 and 224 during 2015-16 and 2016-17, respectively). Irrespective of mulching, number of spike/ $\mathrm{m}^{2}$ increased significantly with increasing the number of irrigation. The trend was similar for the other yield attributes, viz., number of filled grains/spike, panicle length as well as 1000grain weight. The increased number of grains/spike with increasing number of irrigation was previously reported by Brahma et al., (2007).Better moisture availability either due to mulching or due to increased number of irrigation could be the reason for increased values of yield attributes. Increased 1000-grain weight in wheat under increased number of irrigation was earlier reported by Ahmad and Kumar (2015).

\section{Biomass production and yield}

Perusal of data (Table 2) indicated the superiority of BP in terms of biomass production and grain yield over ZT and CT. In both the years of experimentation, significantly higher biomass (8.71 and 8.89 t/ha during 2015-16 and 2016-17, respectively) and grain yield (3.55 and 3.67 t/ha during 2015-16 and 2016-17, respectively) was recorded under $\mathrm{BP}$. The yield increase under BP was 13 and $16.9 \%$ over CT during 2015-16 and 2016-17, respectively. ZT also recorded significantly higher yield (3.26 and 3.45 t/ha during 201516 and 2016-17, respectively) over CT. However, straw yield did not differ significantly under various crop establishment techniques as there was not much variation in straw yield achieved under CT, ZT and BP in both the years of experimentation. Actually the grain-straw ratio was lesser in CT resulting in lesser harvest index value compared to ZT 
and BP, which in turn increased the straw yield under $\mathrm{CT}$ and lower proportionate increase in straw yield under ZT and BP. Bed planting showed higher yields due to improved water use efficiency coupled with better fertilizer use efficiency.

Moreover, the bed planted crops were less prone to lodging. This was in conformity with the findings of Hobbs et al., (2000). Prolonged soil moisture conservation, proper seed rate and seeding depth, uniform seed distribution, line seeding under BP probably had a great role towards higher yield performances as suggested by Gupta et al., (2002).Higher yields under BP over CT was also reported by a number of scientists (Yadav et al., 2009; Alamgir et al., 2015).

Grain yield increased significantly under mulch treated plots over non-mulched plots irrespective of irrigation levels. The treatments comprising three irrigation along with application of straw mulch @ 4 t/ha recorded significantly higher yield (4.27 and 4.21 t/ha during 2015-16 and 2016-17, respectively) over the rest of the treatment combinations in both the years of experimentation.

It was also noted that the grain yield obtained with mulch +1 irrigation was statistically at par with the treatment receiving three irrigation without mulching. Significant variation was found in straw yield also under various mulch $\times$ irrigation levels. With increase in number of irrigation both under mulched and non-mulched plots grain yield increased significantly.

Application of surface mulch enhanced the productivity significantly by improving soil moisture status by restricting the losses due to evaporation particularly at the initial stages of growth over no mulch treatment. Mulch was supposed to be a good option for rice residue management during the wheat crop, especially with no tillage. Mulch could increase yield, water use efficiency and profitability along with improvement in soil health, increased nutrient use efficiency and minimized air pollution while decreasing weed pressure (Singh and Sidhu, 2013).Sarwar et al., (2013) also reported maximum grain yield $(5.16 \mathrm{t} \mathrm{ha}$ ${ }^{1}$ ) in rice straw mulch treatment compared to all other mulch materials.

\section{Water use, productivity and extraction pattern}

Perusal of data indicated that the water use was maximum in CT (264 and $241 \mathrm{~mm}$ in 2015-16 and 2016-17, respectively). Amongst the crop establishment techniques, BP recorded the least total water use (233 and 213 $\mathrm{mm}$ in 2015-16 and 2016-17, respectively). ZT recorded intermediate value between BP and CT (Table 3). Slight elevation of bed under bed planting further helped to conserve more moisture, thereby reducing the extent of profile contribution.

Kumar et al., (2010) reported water saving in wheat under bed planting to the extent of 1431 and $10-27 \%$ in well and poorly drained soils, respectively, depending on rainfall. As far as water use efficiency (WUE) and water productivity were concerned, BP recorded the highest WUE and water productivity in both the years of experimentation. Maurya and Singh (2008) reported that WUE (131.38 and $173.88 \mathrm{~kg} / \mathrm{ha} / \mathrm{cm}$ ) was highest under the bed planting method than conventional (drill) method.

The higher value of WUE in 201617compared to 2015-16 was attributed to higher yield performance together with lesser effective rainfall. Higher yield with lesser water use was the prime factor towards the increased water productivity values in BP and ZT over CT. 
Table.1 Yield attributes of wheat as influenced by mulch $\times$ irrigation treatments under various crop establishment techniques

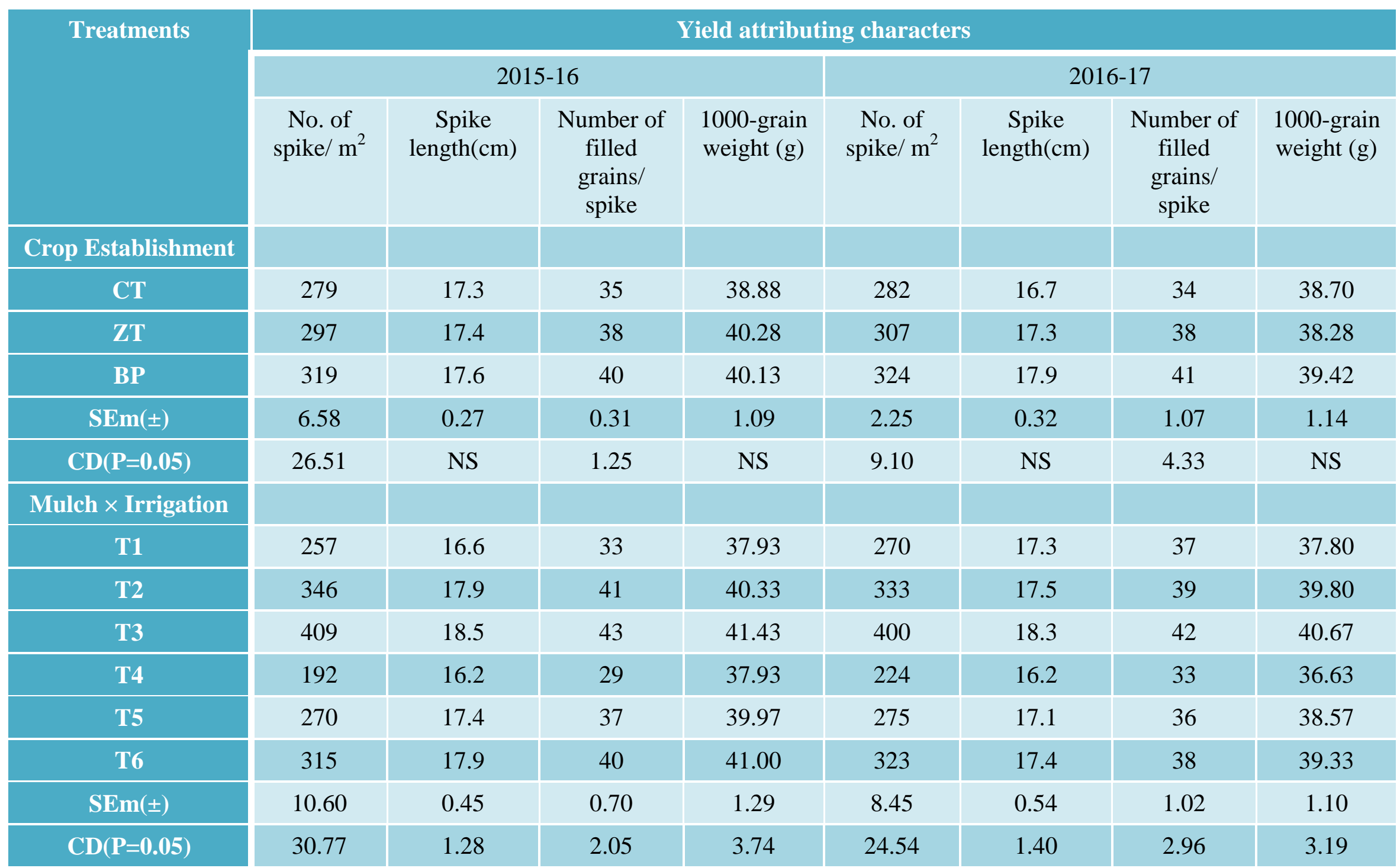

NS- Non-Significant; Treatments details are presented in materials and methods 
Table. 2 Biomass and yield of wheat as influenced by mulch $\times$ irrigation treatments under various crop establishment techniques

\begin{tabular}{|c|c|c|c|c|c|c|c|c|}
\hline \multirow[t]{2}{*}{ Treatments } & \multicolumn{2}{|c|}{ Biomass production(t/ha) } & \multicolumn{2}{|c|}{ Grain yield(t/ha) } & \multicolumn{2}{|c|}{ Straw yield(t/ha) } & \multicolumn{2}{|c|}{ Harvest Index } \\
\hline & $2015-16$ & 2016-17 & $2015-16$ & 2016-17 & $2015-16$ & 2016-17 & $2015-16$ & 2016-17 \\
\hline \multirow{2}{*}{\multicolumn{9}{|c|}{$\begin{array}{l}\text { Crop } \\
\text { Establishment }\end{array}$}} \\
\hline & & & & & & & & \\
\hline CT & 8.36 & 8.15 & 3.14 & 3.14 & 5.33 & 5.33 & 0.34 & 0.37 \\
\hline $\mathbf{Z T}$ & 8.55 & 8.43 & 3.26 & 3.45 & 5.43 & 5.42 & 0.38 & 0.39 \\
\hline BP & 8.71 & 8.89 & 3.55 & 3.67 & 5.56 & 5.77 & 0.39 & 0.39 \\
\hline $\operatorname{SEm}( \pm)$ & 0.09 & 0.11 & 0.03 & 0.03 & 0.11 & 0.19 & 0.01 & 0.02 \\
\hline $\mathrm{CD}(\mathrm{P}=0.05)$ & 0.34 & 0.44 & 0.12 & 0.12 & NS & NS & 0.04 & NS \\
\hline \multirow{2}{*}{\multicolumn{9}{|c|}{$\begin{array}{l}\text { Mulch } \times \\
\text { Irrigation }\end{array}$}} \\
\hline & & & & & & & & \\
\hline T1 & 7.73 & 7.83 & 2.98 & 3.16 & 5.02 & 4.83 & 0.38 & 0.40 \\
\hline T2 & 9.37 & 9.03 & 3.68 & 3.65 & 5.70 & 5.39 & 0.39 & 0.41 \\
\hline T3 & 10.40 & 10.45 & 4.27 & 4.21 & 6.07 & 6.24 & 0.41 & 0.41 \\
\hline T4 & 6.49 & 6.78 & 2.37 & 2.73 & 4.67 & 4.86 & 0.34 & 0.36 \\
\hline T5 & 8.09 & 7.83 & 3.10 & 3.17 & 5.32 & 5.53 & 0.37 & 0.36 \\
\hline T6 & 9.18 & 8.96 & 3.49 & 3.61 & 5.84 & 6.19 & 0.37 & 0.37 \\
\hline $\operatorname{SEm}( \pm)$ & 0.24 & 0.27 & 0.11 & 0.12 & 0.27 & 0.29 & 0.02 & 0.02 \\
\hline $\mathrm{CD}(\mathrm{P}=0.05)$ & 0.70 & 0.78 & 0.32 & 0.35 & 0.77 & 0.86 & 0.05 & 0.05 \\
\hline
\end{tabular}

NS- Non-Significant; Treatments details are presented in materials and methods 
Table.3 Total water use, water use efficiency and water productivity of wheat as influenced by mulch $\times$ irrigation treatments under various crop establishment techniques

\begin{tabular}{|c|c|c|c|c|c|c|}
\hline \multirow[t]{2}{*}{ Treatments } & \multicolumn{2}{|c|}{$\begin{array}{l}\text { Total water } \\
\text { use(mm) }\end{array}$} & \multicolumn{2}{|c|}{$\begin{array}{l}\text { Water use } \\
\text { efficiency }(\mathrm{kg} / \mathrm{ha} / \mathrm{cm})\end{array}$} & \multicolumn{2}{|c|}{$\begin{array}{l}\text { Water } \\
\text { productivity(kg } \\
\text { grain/ } \mathbf{m}^{\mathbf{3}} \text { water use) }\end{array}$} \\
\hline & $2015-16$ & 2016-17 & $2015-16$ & 2016-17 & $2015-16$ & 2016-17 \\
\hline \multicolumn{7}{|c|}{$\begin{array}{c}\text { Crop } \\
\text { Establishment }\end{array}$} \\
\hline CT & 264 & 241 & 12.01 & 13.28 & 1.20 & 1.33 \\
\hline $\mathbf{Z T}$ & 244 & 222 & 13.51 & 15.87 & 1.35 & 1.59 \\
\hline $\mathbf{B P}$ & 233 & 213 & 15.38 & 17.16 & 1.54 & 1.72 \\
\hline $\operatorname{SEm}( \pm)$ & 2.4 & 2.3 & 0.21 & 0.22 & 0.02 & 0.02 \\
\hline $\mathrm{CD}(\mathrm{P}=0.05)$ & 9.2 & 8.6 & 0.80 & 0.84 & 0.06 & 0.07 \\
\hline \multicolumn{7}{|c|}{ Mulch $\times$ Irrigation } \\
\hline $\mathrm{T} 1$ & 188 & 168 & 15.91 & 18.24 & 1.59 & 1.82 \\
\hline $\mathrm{T} 2$ & 232 & 212 & 15.94 & 17.29 & 1.59 & 1.73 \\
\hline T3 & 280 & 258 & 15.51 & 16.53 & 1.55 & 1.66 \\
\hline $\mathrm{T4}$ & 210 & 190 & 11.31 & 14.49 & 1.13 & 1.45 \\
\hline $\mathrm{T5}$ & 262 & 238 & 11.85 & 13.31 & 1.19 & 1.33 \\
\hline T6 & 312 & 285 & 11.26 & 12.75 & 1.13 & 1.28 \\
\hline $\operatorname{SEm}( \pm)$ & 6.3 & 5.9 & 0.42 & 0.47 & 0.04 & 0.04 \\
\hline $\mathrm{CD}(\mathrm{P}=0.05)$ & 18.5 & 17.2 & 1.23 & 1.36 & 0.11 & 0.13 \\
\hline
\end{tabular}

NS- Non-Significant; Treatments details are presented in materials and methods

Table.4 Moisture extraction pattern of wheat as influenced by mulch $\times$ irrigation treatments under various crop establishment techniques

\begin{tabular}{|c|c|c|c|c|c|c|}
\hline & \multicolumn{5}{|c|}{ Moisture extraction pattern (\%) } \\
\hline $\begin{array}{c}\text { Treatments } \\
\text { Crop }\end{array}$ & $0-15 \mathrm{~cm}$ & $15-30 \mathrm{~cm}$ & $30-45 \mathrm{~cm}$ & $0-15 \mathrm{~cm}$ & $15-30 \mathrm{~cm}$ & $30-45 \mathrm{~cm}$ \\
\hline Establishment & & & & & & \\
\hline CT & 41.1 & 34.2 & 24.7 & 40.2 & 33.9 & 25.9 \\
\hline ZT & 38.9 & 35.1 & 26.0 & 39.4 & 34.6 & 26.0 \\
\hline BP & 35.1 & 33.2 & 31.7 & 33.9 & 33.0 & 33.1 \\
\hline Mulch & & & & & & \\
\hline Irrigation & & & & & & \\
\hline T1 & 36.8 & 31.4 & 31.8 & 35.9 & 32.3 & 31.8 \\
\hline T2 & 41.0 & 32.6 & 26.4 & 38.5 & 33.6 & 27.9 \\
\hline T3 & 42.3 & 32.4 & 25.3 & 40.7 & 33.0 & 26.3 \\
\hline T4 & 29.4 & 36.8 & 33.8 & 28.3 & 37.1 & 34.6 \\
\hline T5 & 36.4 & 32.4 & 31.2 & 37.0 & 32.5 & 30.5 \\
\hline T6 & 38.6 & 34.2 & 27.2 & 39.1 & 33.9 & 27.0 \\
\hline
\end{tabular}

Treatments details are presented in materials and methods 
Table.5 Production economics of wheat cultivation under various treatments

\begin{tabular}{|c|c|c|c|c|c|}
\hline $\begin{array}{c}\text { Crop Estab. } \\
\text { Tech. }\end{array}$ & $\begin{array}{l}\text { Mulch } \times \\
\text { Irrigation }\end{array}$ & $\begin{array}{c}\text { Cost of } \\
\text { cultivation( } \square / h \text { a) }\end{array}$ & $\begin{array}{c}\text { Gross } \\
\text { return( } \square / \mathbf{h a})\end{array}$ & $\begin{array}{l}\text { Net return } \\
(\square / \mathrm{ha})\end{array}$ & $\mathrm{B}:$ C ratio \\
\hline \multirow[t]{6}{*}{ CT } & $\mathrm{T} 1$ & 34419 & 43350 & 8931 & 1.26 \\
\hline & $\mathrm{T} 2$ & 35144 & 52200 & 17056 & 1.49 \\
\hline & T3 & 36594 & 59400 & 22806 & 1.62 \\
\hline & $\mathrm{T} 4$ & 31044 & 34200 & 3156 & 1.10 \\
\hline & T5 & 31769 & 43800 & 12031 & 1.38 \\
\hline & T6 & 33219 & 49200 & 15981 & 1.48 \\
\hline \multirow[t]{6}{*}{$\mathrm{ZT}$} & $\mathrm{T} 1$ & 26641 & 42750 & 16109 & 1.60 \\
\hline & $\mathrm{T} 2$ & 27366 & 53400 & 26034 & 1.95 \\
\hline & T3 & 28816 & 61800 & 32984 & 2.14 \\
\hline & $\mathrm{T} 4$ & 23266 & 36900 & 13634 & 1.59 \\
\hline & T5 & 23991 & 45150 & 21159 & 1.88 \\
\hline & T6 & 25441 & 53550 & 28109 & 2.10 \\
\hline \multirow[t]{6}{*}{ BP } & $\mathrm{T} 1$ & 24316 & 47850 & 23534 & 1.97 \\
\hline & $\mathrm{T} 2$ & 25041 & 59850 & 34809 & 2.39 \\
\hline & T3 & 26491 & 71100 & 44609 & 2.68 \\
\hline & $\mathrm{T} 4$ & 20941 & 35550 & 14609 & 1.70 \\
\hline & T5 & 21666 & 50550 & 28884 & 2.33 \\
\hline & T6 & 23116 & 54300 & 31184 & 2.35 \\
\hline
\end{tabular}

Treatments details are presented in materials and methods

Among various mulch $\times$ irrigation levels, the mulched plots recorded lower water use (188280 and $168-258 \mathrm{~mm}$ during year I and II, respectively) as compared to non-mulch treatments (210-312 and 190-285 mm during year I and II, respectively) in both the years of experimentation. Straw mulching was helpful in conservation of profile moisture and thereby reduced the moisture loss due to evaporation particularly at initial growth stages which in turn resulted in lower water use. Decreased evapo-transpiration in wheat under mulch treated plots was previously reported by Huang et al., (2005). During initial period a considerable amount of moisture gets lost through evaporation under non-mulch treatment resulting in higher water use. It was noted that with increase in number of irrigation, the total water use increased significantly both under mulched and nonmulched plots. The variation between two years of experimentation (lower values in second year) was due to variation in rainfall received by the crop during the growing season. Irrespective of irrigation levels, mulched plots recorded higher WUE and water productivity values against the nonmulched plots. Increased WUE in mulch treated plot was previously reported by Singh and Sidhu (2013). 'Irrigation water-use efficiency for grain yield decreased with increasing irrigation level' was in conformity with the findings of Huang et al., (2005). The plots in which irrigation applied thrice, those plots recorded the lowest value of water use efficiency as well as water productivity.

Under all three crop establishment techniques, top layer $(0-15 \mathrm{~cm})$ contributed maximum (41.1 and $40.2 \%$ in ZT, 38.9 and $39.4 \%$ in BP and 35.1 and $33.9 \%$ in CT during 2015-16 and 2016-17, respectively) towards total 
water use (Table 4). Under ZT, moisture availability in top $0-15 \mathrm{~cm}$ was recorded higher over BP probably due to more residue retention of previous rice crop under ZT.

In plots where straw mulch was applied @4 t/ha, contribution of $0-15 \mathrm{~cm}$ layer was recorded to be maximum. The soil moisture extraction status was affected due to application of mulch; with the application of straw mulch, the top layer recorded higher availability of moisture and thereby contributed more towards consumptive use compared with the other two layers. While in non-mulch treatment, there was no definite trend in contributing the moisture extraction pattern. Increase in number of irrigation further increased the moisture availability in top $0-15 \mathrm{~cm}$ soil layer; that why the contribution of top $0-15 \mathrm{~cm}$ soil layer was maximum. Mitra and Das (2015) reported that with increase in number of irrigation in wheat, the contribution of upper layer was increased due to more availability of required soil moisture. The plots in which irrigation and mulch was not applied the availability of soil moisture was less in surface layer for which the roots have to penetrate deeper layer for getting the required moisture. This led to higher contribution of $15-30 \mathrm{~cm}$ layer instead of the $0-15 \mathrm{~cm}$ soil layer.

\section{Production economics}

As far as cost of production was concerned the maximum cost of cultivation was recorded under CT irrespective of mulching and irrigation levels during both the years. Among various crop establishment techniques BP showed superiority over CT and ZT due to less cost involvement. No extra cost was incurred towards land preparation both under ZT and BP. Moreover, chemical weed control was performed in these two types of crop establishment techniques which resulted in about $\square$ 70008000/ ha of overall savings over CT (Table 5). Less fuel requirement as well as less labour engagement for harvesting resulted in further cost saving under two wheel drive bed planter over zero till planted wheat. In all crop establishment techniques higher cost was involved where mulching was performed and more number of irrigation applied. Sharma et al., (2007) reported that bed planter of wheat saved about $86.1 \%$ time as well as $29.8 \%$ cost of sowing over conventional method.

The variation in gross return was attributed to the difference in yield achieved under various irrigation $\times$ mulch levels under various crop establishment techniques. In all the cases, gross return was higher in $\mathrm{BP}$ over $\mathrm{ZT}$ and $\mathrm{CT}$ due to higher economic yield obtained under BP. Mollah et al., (2009) reported lower cost of cultivation with higher gross return, gross margin and benefit-cost ratio in bed planting than conventional method because weed infestation was less in bed planting and it saved 41-48 \% irrigation water. The trend was similar for net return also where plots irrigated thrice along with paddy straw mulch recorded the highest net return. Ahmad et al., (2013) reported that sowing of wheat in residual moisture through zero tillage technology increased net return on sustained basis. Alamgir et al., (2015) reported that bed planting technique gave significantly $14 \%$ higher grain yield over the conventional tillage systems. Comparing cost and benefit, bed planting reduced cultivation costs (ploughing, seeding, weeding, irrigation) by around $30 \%$ compared to conventional tillage. The maximum B: $\mathrm{C}$ ratio (2.68) was recorded under BP with mulching and three irrigations. In general $\mathrm{BP}$ and $\mathrm{ZT}$ planted crop expressed superior $\mathrm{B}$ : $\mathrm{C}$ ratio compared to $\mathrm{CT}$ during both the years. Lesser cost involvement with higher yield performance under $\mathrm{BP}$ and $\mathrm{ZT}$ resulted in superior B: $\mathrm{C}$ ratio over $\mathrm{CT}$. In some cases, mulch treated plots resulted in lesser B: C ratio against non-mulched plots. 
The cost involved towards mulching could not compensate the degree of yield enhancement, though the yield recorded under mulched plots were always higher than nonmulched plots.

It can be concluded that BP along with paddy straw mulching@ 4 t/ha and three irrigations at CRI, booting and milking is a good option for the wheat farmers of the Eastern $s u b$ Himalayan plains in terms of productivity, water use and profitability.

\section{References}

Ahmad, A. and Kumar, R. 2015. Effect of irrigation scheduling on the growth and yield of wheat genotypes. Agriltural Science Digest 35 (3): 199-202.

Ahmad, P., Hussain, M., Ahmad, S., Ahmad, M., Tabassam, R. and Shabbir, I. 2013. Comparison of different tillage practices among various wheat varieties. Applied Scientific Reports 4(2): 203-209.

Alamgir, A.M., Mohi, U.M., Prasad, T. and Marufa, F. 2015. Performance of wheat varieties under different tillage systems in Bangladesh. In: Conference on International Research on Food Security, Natural Resource Management and Rural Development at Berlin, Germany during September 1618 , Berlin.

Bhuyan, M.H.M., Ferdousi, M.R. and Iqbal, M.T. 2012. Yield and growth response to transplanted aman rice under raised bed over conventional cultivation method. ISRN Agronomy: 01-08.

Brahma, R., Janawade, A.D. and Palled, Y.B. 2007. Effect of irrigation schedules, mulch and anti-transpirant on growth, yield and economics of wheat. Karnataka Journal of Agricultural Science 20(1):6 - 9.

Chauhan, D., Sharma, R.K. and Chhokar, R.S. 2003. Comparative performance of tillage options in wheat (Triticum aestivum) productivity and weed management. Indian Journal of Agricultural Sciences 73 (7): 402-406.

Das, S. and Mitra, B. 2011. Performance of different wheat genotypes under various levels of nitrogen in rainfed condition of terai region of West Bengal. Journal of Crop and Weed 7 (1): 23-25.

Dilip Kumar, G., Sachin, S.S. and Rajesh, K. 1990. Importance of mulch in crop production. Indian Journal of Soil Conservation 18: 20-26.

Gupta, R.K., Hobbs, P.R., Ladha, J.K. and Prabhakar, S.V.R.K. 2002. Resource Conserving Technologies: Transforming the Rice-Wheat systems of the Indo-Gangetic Plains. In: RiceWheat Consortium-A success story. Published by Asia-Pacific Association of Agricultural Research Institution, FAO Regional Office for Asia and The Pacific Bangkok. pp 42.

Hobbs, P.R., Singh, Y., Giri, S.G., Lauren, J.G. and Dusbury, J.M. 2000. Direct seeding and reduced tillage options in the rice-wheat systems of the IndoGagnetic plains of South Asia. Paper presented at IRRI workshop, Bankok, Thailand during 25-28 January.

Huang, Y., Chen, L., Fu, B. And Gong, J. 2005. The wheat yields and water-use efficiency in the Loess Plateau: Straw mulch and irrigation effects. Agrilcultural Water Management 72 (3): 209-222.

Kumar, V., Kumar, P., Singh, K. and Singh, R.2010. Water use efficiency in ricewheat cropping sequence on raised bed planting system. Annals of Agri Bio Research 18 (1): 32-34.

Mann, R. A., Ramzan, M. and Munir, A. 2008. Improving the sustainability of wheat production in irrigated areas of Punjab, Pakistan through conservation tillage technology. International 
Journal of Agriculture and Biology 10 (3): 249-254.

Maurya, R.K. and Singh, G.R. 2008. Effect of crop establishment methods and irrigation schedules on economics of wheat (Triticum aestivum L.) production, moisture depletion pattern, consumptive use and crop water use efficiency. Indian Journal of Agricultural Sciences 78(10):830-833.

Mitra, B. and Das, S. 2015. Economization of irrigation schedule in wheat cultivation under sub-Himalayan plains of West Bengal. Journal of Crop and Weed 11(2): 122-126.

Mollah, M.I.U., Bhuiya, M.S.U. and Kabir, M.H. 2009. Bed Planting - A new crop establishment method for wheat in ricewheat cropping system. Journal of Agriculture and Rural Development 7 (1\&2):23-31.

Naresh, R. K., Gupta, R. K., Gangwar, L. K., Kumar, A., Singh, P. K. and Tomar, S. S. 2011. Wheat cultivars and nitrogen placement on yield and yield contributing characters of wheat in relation to resource conservation technologies. Plant Arch 11 (2):665671.

Nayar, V.K. and Gill, M.S. 1994. Water management constraints in rice-wheat rotations in India. In: 'Wheat in heat stressed environments: irrigated, dry areas and rice-wheat farming system', eds. by D.A. Saunders and G.P Hattel. CIMMYT, Mexico DF. pp. 328-338.

Sarwar, M.A., Akbar, N., Javeed, H.M.R., Shehzad, M.A., Mehmood, A. and Abbas, H.T.2013. Response of zero tilled wheat crop to different mulching techniques in a semiarid environment. International Journal of Advanced Research 1 (9): 768-776.

Sharma, M.K., Sharma, R.P. and Kumar, R.2007. Effect of tillage and planting management on field operations and energetics in rice-wheat cropping system. Journal of Applied Biology 17 (1/2): 52-55.

Singh, Y. and Sidhu, H.S. 2013. Management of cereal crop residues for sustainable rice-wheat production system in the Indo-Gangetic Plains of India. Proceedings of National Academy of Sciences 80(1): 95-114.

Yadav, R.L. 1998. Factor productivity trends in a rice-wheat cropping system under long-term use of chemical fertilisers. Experimental Agriculture 34: 1-18.

Yadav, S.S., Das, S. N., Sinha, S.P. and Kumar, M. 2009. Effect of resource conservation tillage practices and cultivars on sustainable wheat (Triticum asteivum L.) production. Journal of Applied Biology 19 (1-2): 56-60.

\section{How to cite this article:}

Prantick Singha, Triptesh Mondal, Koushik Patra and Biplab Mitra. 2018. Straw Mulch and Restricted Irrigation Effect on Productivity, Profitability and Water Use in Wheat (Triticum aestivum L.) under Various Crop Establishment Techniques in Eastern Sub-Himalayan Plains of India. Int.J.Curr.Microbiol.App.Sci. 7(02): 1521-1533.

doi: https://doi.org/10.20546/ijcmas.2018.702.183 